Corrigendum

\title{
Corrigendum to "Effects of Cannabinoid Exposure during Adolescence on the Conditioned Rewarding Effects of WIN 55212-2 and Cocaine in Mice: Influence of the Novelty-Seeking Trait"
}

\author{
M. Rodríguez-Arias, C. Roger-Sánchez, I. Villanova, N. Revert, C. Manzanedo, \\ J. Miñarro, and M. A. Aguilar
}

Unidad de Investigación Psicobiología de las Drogodependencias, Departamento de Psicobiologia, Facultad de Psicología, Universidad de Valencia, 46010 Valencia, Spain

Correspondence should be addressed to M. A. Aguilar; asuncion.aguilar@uv.es

Received 11 April 2016; Accepted 12 May 2016

Copyright (C) 2016 M. Rodríguez-Arias et al. This is an open access article distributed under the Creative Commons Attribution License, which permits unrestricted use, distribution, and reproduction in any medium, provided the original work is properly cited.

In the article titled "Effects of Cannabinoid Exposure during Adolescence on the Conditioned Rewarding Effects of WIN 55212-2 and Cocaine in Mice: Influence of the NoveltySeeking Trait", [1] the name of the third author was given incorrectly as I. Vilanova. The author's name should have been written I. Villanova. The revised author list is shown above.

\section{References}

[1] M. Rodríguez-Arias, C. Roger-Sánchez, I. Vilanova et al., "Effects of cannabinoid exposure during adolescence on the conditioned rewarding effects of WIN 55212-2 and cocaine in mice: influence of the novelty-seeking trait," Neural Plasticity, vol. 2016, Article ID 6481862, 11 pages, 2016. 

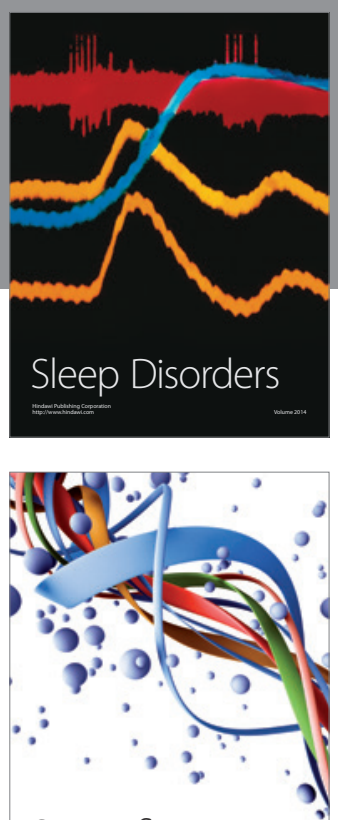

Scientifica
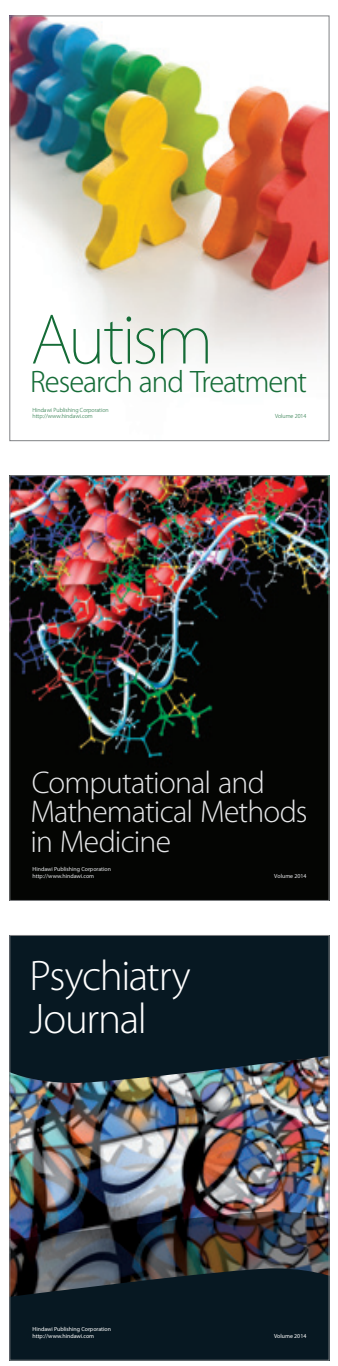
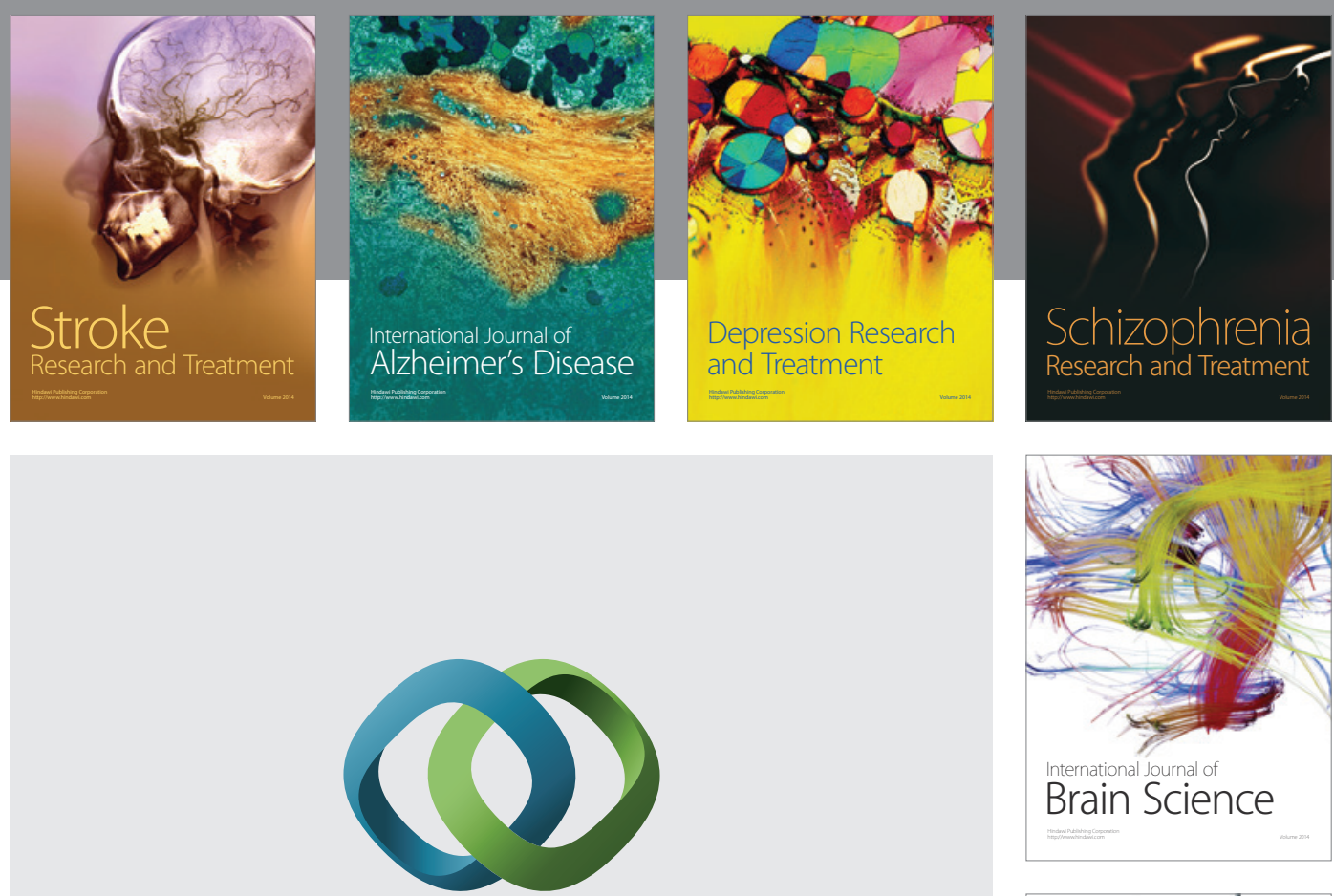

\section{Hindawi}

Submit your manuscripts at

http://www.hindawi.com
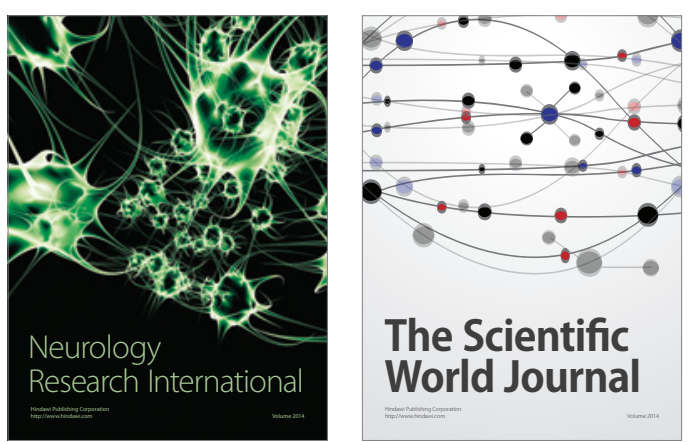

The Scientific World Journal

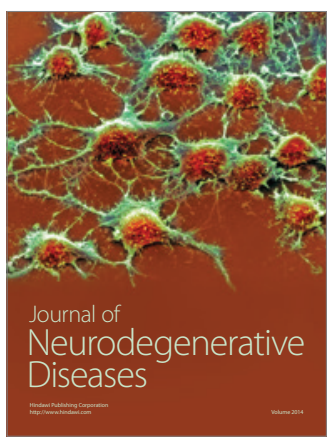

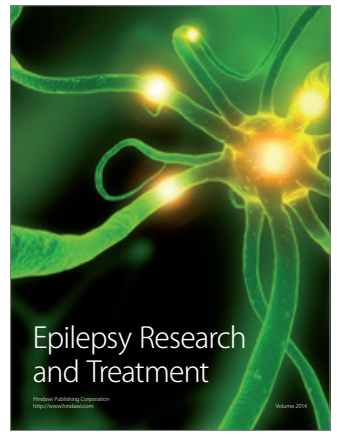

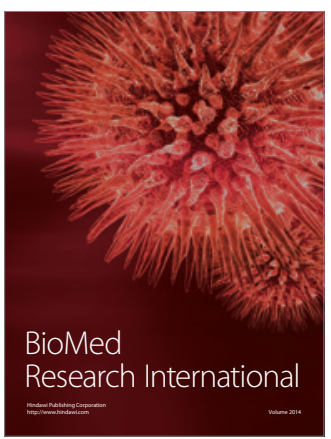

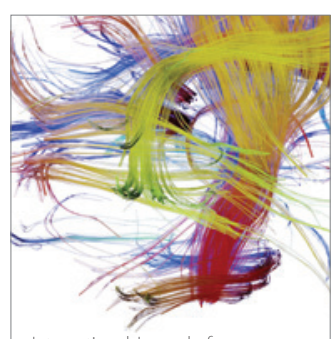

Brain Science

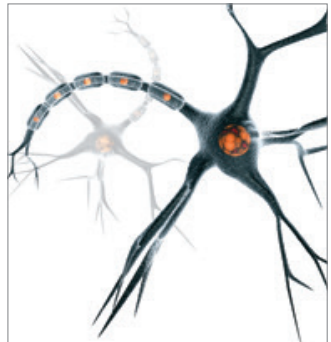

Neural Plasticity
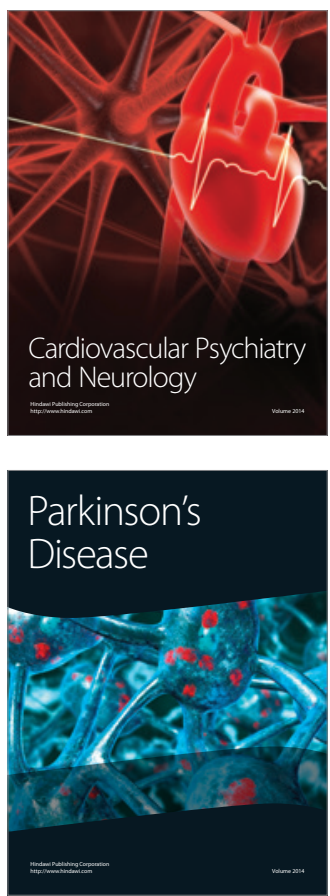